\title{
Renal insufficiency with combinations of angiotensin converting enzyme inhibitors and diuretics
}

\author{
B F MURPHY, JUDITH A WHITWORTH, PRISCILLA KINCAID-SMITH
}

The use of angiotensin converting enzyme inhibitors in hypertensive patients with bilateral renal artery stenosis is associated with reversible impairment of renal function. ${ }^{12}$ Deterioration in renal function may not occur until diuretics are added to the angiotensin converting enzyme inhibitors and may reverse after the diuretics are discontinued. ${ }^{2}$

We report two episodes of renal impairment after treatment with combinations of diuretic and two different angiotensin converting enzyme inhibitors in a patient with hypertensive nephrosclerosis. This case is of added interest in that, though the patient had severe small renal vessel disease, major renal artery stenosis was not present.

\section{Case report}

A 39 year old housewife presented in 1980 with headache and blurred vision. Her blood pressure was $270 / 140 \mathrm{~mm} \mathrm{Hg}$, and grade IV hypertensive retinopathy was noted. Plasma creatinine concentration was $170 \mu \mathrm{mol} / 1(1.9 \mathrm{mg} / 100 \mathrm{ml})$, and an intravenous pyelogram showed a $13 \mathrm{~cm}$ left kidney and a $10.5 \mathrm{~cm}$ right kidney. A micturating cystourethrogram showed no abnormality, and a renal angiogram showed two renal arteries with no evidence of renal artery stenosis. Peripheral plasma renin concentration was normal ( $19 \mathrm{mIU} / 1$ plasma), and renal vein renin estimation showed no appreciable gradient $(1: 1 \cdot 1)$. A left renal biopsy showed severe intimal fibroelastosis of the small arteries and arterioles, with total occlusion of some vessels.

A provisional diagnosis of right sided reflux nephropathy and hypertensive nephrosclerosis was made, and she was treated with propranolol ( $320 \mathrm{mg} /$ day), prazosin $(15 \mathrm{mg} /$ day), and chlorothiazide (1 $\mathrm{g} /$ day). Because of persistence of moderate hypertension (150/ $100 \mathrm{~mm} \mathrm{Hg}$ ) after one month treatment was changed to captopril and frusemide. Over five days her blood pressure was reduced (130/ $85 \mathrm{~mm} \mathrm{Hg}$ ) with $75 \mathrm{mg}$ captopril and $120 \mathrm{mg}$ frusemide daily. Eight days after starting captopril, plasma creatinine concentration rose to $280 \mu \mathrm{mol} / 1(3.2 \mathrm{mg} / 100 \mathrm{ml})$. Two days later a generalised rash developed and captopril was stopped. Blood pressure remained well controlled with methyldopa ( $2 \mathrm{~g} /$ day $)$ and chlorothiazide $(1 \mathrm{~g} /$ day $)$, and 12 days later plasma creatinine had returned to $170 \mu \mathrm{mol} / \mathrm{l}$ $(1.9 \mathrm{mg} / 100 \mathrm{ml})$.

In May 1983 she was readmitted to hospital for a trial of treatment with enalapril (MK 421) because of poor blood pressure control.

\section{Department of Medicine, University of Melbourne, Australia} PRISCILLA KINCAID-SMITH, MD, DSC, professor of medicine

Department of Nephrology, The Royal Melbourne Hospital, Melbourne, Australia

JUDITH A WHITWORTH, MD, PHD, assistant director

B F MURPHY, MB, BS, registrar

Correspondence to: Dr Judith A Whitworth, Department of Nephrology, The Royal Melbourne Hospital, Parkville 3050, Australia.
The use of angiotensin converting enzyme inhibitors in combination with diuretics may lead to reversible renal insufficiency in patients with renal vascular disease

She was well on admission with a blood pressure of $150 / 101 \mathrm{~mm} \mathrm{Hg}$. Plasma creatinine concentration had improved to $110 \mu \mathrm{mol} / 1(1.2 \mathrm{mg} /$ $100 \mathrm{ml}$ ) with a creatinine clearance of $0.7 \mathrm{ml} / \mathrm{s}$. Enalapril was administered in increasing doses to a maximum of $20 \mathrm{mg}$ twice daily which was continued for five days. Frusemide $(80 \mathrm{mg} /$ day $)$ and chlorothiazide $(500 \mathrm{mg} /$ day) were added on day 3 . Blood pressure gradually came under control and on day 4 was $130 / 90 \mathrm{~mm} \mathrm{Hg}$, but plasma creatinine had risen to $140 \mu \mathrm{mol} / 1(1.6 \mathrm{mg} / 100 \mathrm{ml})$. The next day blood pressure was $115 / 80 \mathrm{~mm} \mathrm{Hg}$ and plasma creatinine $230 \mu \mathrm{mol} / 1(2.6 \mathrm{mg} / 100 \mathrm{ml})$. Enalapril and frusemide were stopped and methyldopa restarted. Blood pressure remained well controlled, and plasma creatinine fell over three days to $120 \mu \mathrm{mol} / \mathrm{l}(1.4 \mathrm{mg} /$ $100 \mathrm{ml}$ ). The figure shows the changes in plasma creatinine during both episodes.

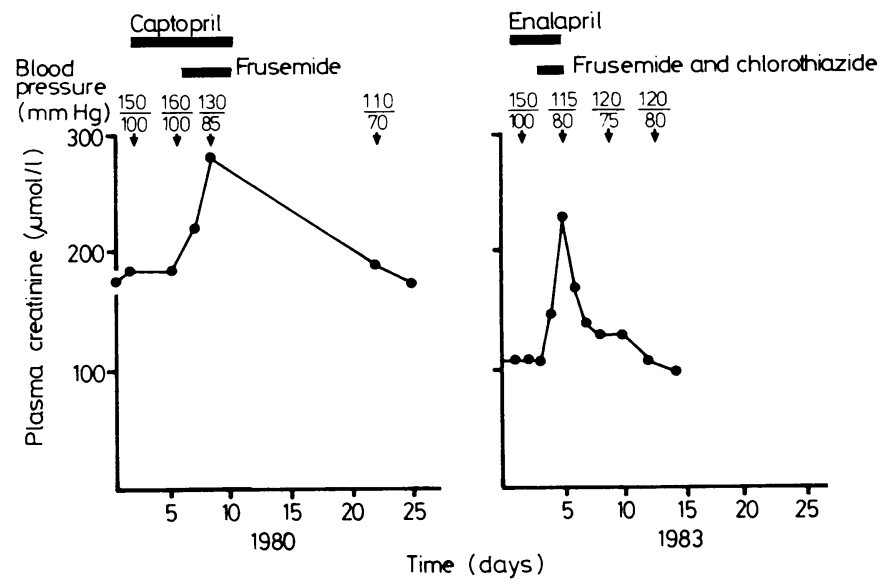

Changes in plasma creatinine concentrations during both episodes of treatment for hypertension.

Conversion: SI to traditional units-Creatinine: $1 \mu \mathrm{mol} / 1 \approx 0.0113 \mathrm{mg} /$ $100 \mathrm{ml}$.

A left renal biopsy was performed 24 hours after enalapril was stopped and this again showed severe vessel lesions, similar to those found at the previous biopsy, but no evidence of acute interstitial nephritis. A repeat renal angiogram again showed no renal artery stenosis. Her blood pressure remains well controlled on methyldopa ( $2 \mathrm{~g} /$ day), hydrochlorothiazide $(50 \mathrm{mg} /$ day), and metoprolol (100 mg/ day), and her renal function is stable. 


\section{Comment}

The mechanism underlying these episodes of acute renal impairment is unclear. The biopsy excluded a sensitivity acute interstitial nephritis which we have recently reported with captopril. ${ }^{3}$ In neither episode was there hypotension before the development of impaired function. The maximal fall in diastolic blood pressure after treatment with both angiotensin converting enzyme inhibitors was only $20 \mathrm{~mm} \mathrm{Hg}$. A small (1 kg) weight loss occurred after administration of diuretics in both cases, but the weight was not regained before return of renal function. Prerenal factors, therefore, seem unlikely to explain the impairment of renal function.

Transient renal impairment in patients with renal artery stenosis, when treated with angiotensin converting enzyme inhibitors, may be the result of inhibition of the action of angiotensin II on the efferent arteriole, a mechanism important in maintaining glomerular filtration rate in the hypoperfused kidney. ${ }^{4}$ In animal studies the fall in glomerular filtration rate with angiotensin converting enzyme inhibition is enhanced by sodium depletion, ${ }^{4}$ and this may explain the additional effect of treatment with diuretics. ${ }^{2}$ Our patient had normal renal arteries on arteriography but multiple severe small vessel lesions on the biopsy specimen, and thus it is possible that similar mechanisms may be operating in her case.

We suggest that caution be exercised when prescribing angiotensin converting enzyme inhibitors in combination with diuretics in patients with both small and large renal vascular disease.

\section{References}

${ }^{1}$ Hricik DE, Browning PJ, Kopelman R, Goorno WE, Maduis NE, Dzau VJ. Captopril-induced functional renal insufficiency in patients with bilateral renal artery stenoses or renal artery stenosis in a solitary kidney. N Engl f Med 1983;308:373-6.

2 Watson ML, Bell GM, Muir AL, Buist TAS, Kellett RJ, Padfield PL. Captopril/diuretic combinations in severe renovascular disease: a cautionary note. Lancet 1983 ;ii:404-5.

${ }^{3}$ Hooke D, Walker R, Walter NMA, d'Apice AJF, Whitworth JA, Kincaid-Smith $P$. Repeated renal failure with use of captopril in a cystinotic renal allograft recipient. $\mathrm{Br} \mathrm{Med} \mathcal{F}$ 1982;285:1538.

${ }^{4}$ Hall JE, Coleman TG, Guyton AC, Balfe JW, Salgado HC. Intrarenal role of angiotensin II and (des-Asp') angiotensin II. Am $\mathcal{F}$ Physiol $1979 ; 236$ :F252-9.

(Accepted 5 October 1983)

\title{
Medical History
}

\section{The rise and fall of surgery for the "floating" kidney}

\author{
DOUGLAS L MCWHINNIE, DAVID N H HAMILTON
}

\begin{abstract}
The latter half of the nineteenth century produced a remarkable expansion of surgical practice. Although most of these new techniques and concepts were soundly based, others, such as the movable or floating kidney, were later ridiculed and discredited.

In Glasgow Royal Infirmary during the 48 years from 1880, when movable kidney was first mentioned in the annual reports of the hospital, to 1928472 patients $(89 \%$ female) were diagnosed as suffering from the condition. Nearly half of them (216) underwent operation and the operative mortality was low. In the first decade of this century an average of 18 cases a year were admitted to the wards of the infirmary. From 1915 to 1920 the number of cases dropped, as did the proportion undergoing operation, but in the 1920s the numbers increased again.

In common with other ineffective treatments for imaginary diseases, operations for the movable kidney simply faded away in Britain in the 1930s.
\end{abstract}

University Department of Surgery, Western Infirmary, Glasgow G11 6NT

DOUGLAS L MCWHINNIE, FRCS, surgical registrar

DAVID N H HAMILTON, PHD, FRCS, consultant surgeon

Correspondence to: Mr David N H Hamilton, Wellcome Unit for History of Medicine, University of Oxford, 47 Banbury Road, Oxford OX2 6PE.

\section{Introduction}

In the second half of the nineteenth century there was a notable expansion of surgical practice. New techniques appeared rapidly after the introduction and implementation of antisepsis and anaesthesia. Although most of this new surgical practice was soundly based, this confidence also produced diagnoses and even operations that were later ridiculed and discredited. One such disorder was the "movable" or "floating" kidney.

This condition had been noted in earlier times, ${ }^{1}$ but it became increasingly popular as a diagnosis in the late nineteenth century, when it was applied to those patients with abdominal symptoms and a kidney that on palpation was alleged to be abnormally mobile.

Early attempts to treat this disorder with nephrectomy led to an appalling mortality. ${ }^{2}$ In 1881 , however, Dr Ernest Hahn of Leipzig described a less radical operation in which the renal capsule and parenchyma were sutured to the adjacent muscle and fascia thus immobilising the kidney (fig 1). ${ }^{3}$ This fixation procedure of nephrorrhaphy (also termed "nephropexy," especially in French publications) was increasingly performed both in hospitals and in private practice until the 1930s, when the concept of the movable kidney was discredited.

We undertook a quantitative study of the rise and fall of surgery for movable kidney. The annual reports of the Glasgow Royal Infirmary contained a valuable clinical section that summarised in some detail the causes of admission to that hospital, the operations performed, and their mortality. Moreover, these records are continuous and are consistently reported, thus providing the opportunity to study the management of movable kidney in that hospital. 